\title{
Rosyjskie złożenia z formantem paradygmatycznym w grupie leksykalno- -semantycznej „Nazwy osób, wyodrębnione ze względu na zawód lub rodzaj działalności” i ich polskie odpowiedniki
}

System leksykalny nieustannie się powiększa, korzystając z różnego rodzaju sposobów nominacji. Nowe jednostki językowe są tworzone w wyniku operacji słowotwórczych, poprzez zapożyczanie lub kalkowanie wyrazów obcych, derywację semantyczną oraz tworzenie nazw wielowyrazowych. Na tę różnorodność, a co za tym idzie - potrzebę badań mających na celu określenie relacji między poszczególnymi sposobami nominacji w języku, jako pierwszy wskazał w latach pięćdziesiątych XX wieku Aleksander W. Isaczenko' ${ }^{1}$, później myśl tę rozwijał Milosz Dokulil². Motywacja słowotwórcza, traktowana jako sposób nominacji korzystający z wewnętrznych zasobów języka - inwentarza środków słowotwórczych, stanowi ponadto centralne zagadnienie publikacji Мотиваиия в словообразовательной системе русского языка Igora S. Ułuchanowa. Autor skupia w niej swoją uwagę na miejscu motywacji słowotwórczej w systemie leksykalnym i w tekście. Uzasadnia, dlaczego tak istotna jest analiza wyrazów motywowanych na tle całości słownictwa, zaznaczając, że wyrazy motywowane stanowią większą część leksyki. Jego zdaniem zbadanie procesów słowotwórczych pozwala zrekonstruować mechanizmy nominacji i wskazać, jakie elementy rze-

1 А.В. Исаченко, К вопросу о структурной типологии словарного состава славянских литературных языков, „Slavia” 27, 1958, z. 3, s. 334-352.

${ }^{2}$ M. Dokulil, Ke koncepci porovnávací charakteristiky slovanských jazyků v oblasti „,tvořeni slov”, „Slovo a slovesnost” 24, 1963, z. 2, s. 85-105. 
czywistości pozajęzykowej zostały odzwierciedlone w języku³ ${ }^{3}$ Przeprowadzając dychotomiczny podział słownictwa na wyrazy motywowane i niemotywowane, można określić udział słowotwórczych i niesłowotwórczych sposobów nominacji w procesie tworzenia nowych wyrazów, a tym samym zbadać, jakie jest miejsce wyrazów motywowanych na tle reszty słownictwa, co może stworzyć nowe perspektywy badawcze.

W niniejszym artykule chciałabym zaprezentować częściowe wyniki badań mających na celu zbadanie relacji między jednostkami językowymi powstałymi w wyniku działania różnych sposobów nominacji. Zostały one przeprowadzone na ograniczonym wycinku leksyki — odpowiadających sobie grupach leksykalno-semantycznych w dwóch językach słowiańskich: rosyjskim i polskim. Przedmiotem badań są nazwy osób, wyodrębnione ze względu na wykonywany zawód, specjalność, rodzaj zajęcia, charakter działalności. Tego typu analiza daje możliwość zrekonstruowania procesów tworzenia nazw zawodowych, czyli określenie, jak ludzie nazywają (a przez to postrzegają) samych siebie z perspektywy wykonywanego zawodu, a co za tym idzie - pełnionej funkcji w społeczeństwie i gospodarce. Zważywszy, że praca zajmuje większą część życia dorosłego człowieka i określa go jako członka społeczeństwa, zasadnym wydaje się zbadanie tej sfery leksyki zarówno z punktu widzenia semantyki, jak i mechanizmów nominacji.

Monografie poświęcone nazwom zawodów w językach słowiańskich to głównie opracowania o charakterze historycznym, dotyczące dziejów nazw konkretnych zawodów ${ }^{4}$, a także ich występowania na obszarze Słowiańszczyzny ${ }^{5}$.

Źródłem materiału dla języka rosyjskiego, który stanowił punkt wyjścia w badaniach, jest podrozdział słownika semantycznego pod tytułem Названия лии по профессии, специальности, роду занятий, характеру деятельности и связанным с ними действиям, отношениям ${ }^{6}$. Materiał dla języka polskiego zebrałam, znajdując ekwiwalenty znaczeniowe dla słownictwa rosyjskiego w oparciu o słowniki dwujęzyczne. W badanej grupie leksykalno-semantycznej w języku rosyjskim występuje około 2750 jednostek leksykalnych, które przeanalizowałam pod kątem słowotwórczym, wspomagając się słownikami gniazd słowotwórczych. Spośród nazw reprezentujących niemalże wszystkie istniejące sposoby nominacji (derywaty proste, złożone, skrótowce, zapożyczenia, wyrazy rodzime, derywaty semantyczne, nazwy wielowyrazowe) jako przedmiot dalszej analizy wybrałam dość wąski wycinek leksyki — określoną klasę derywatów, którą tworzą złożenia

${ }^{3}$ И.С. Улуханов, Мотивация в словообразовательной системе русского языка, Москва 2005, s. 68-69.

${ }^{4}$ Zob. m.in. J. Rusek, Dzieje nazw zawodów w językach słowiańskich, Warszawa 1996; J. Siatkowski, Stowiańskie nazwy wykonawców zawodów w historii i dialektach, Warszawa 2005.

${ }^{5}$ Ogólnostowiański atlas językowy. Seria leksykalno-stowotwórcza, t. 8. Zawody i życie spoteczne, red. J. Basara, J. Siatkowski, A. Basara, Warszawa 2003.

${ }^{6}$ Русский семантический словарь. Толковый словарь, систематизированный по классам слов и значений, t. 1, red. Н.Ю. Шведова, Москва 2002, s. 195-325. 
z formantem paradygmatycznym, w nomenklaturze rosyjskiej nazywanym sufiksem zerowym (нулевой суффикс).

W niniejszym artykule chciałabym przedstawić różnice w sposobie tworzenia nazw osób w obu językach poprzez przeanalizowanie, jakiego rodzaju ekwiwalenty występują $\mathrm{w}$ języku polskim dla jednego, określonego typu formacji słowotwórczych w języku rosyjskim (w tym przypadku złożeń z formantem paradygmatycznym) w ramach badanej grupy leksykalno-semantycznej. Composita stanowią około $12 \%$ całego materiału, z czego do dalszej analizy wybrałam 82 złożenia z formantem paradygmatycznym. Dla 80 z nich podstawą słowotwórczą jest połączenie $\mathrm{S}+\mathrm{V}$, na przykład: винодел, звездочёm, водолив, зверобой, dla 2 - Ad + V: скороход, живодёр. Wszystkie wyrazy w tej grupie są nazwami wykonawców czynności, wyrażonej czasownikiem w końcowym członie złożenia i skonkretyzowanej przez człon pierwszy ${ }^{7}$. Ogólną parafrazę słowotwórczą można sformułować następująco: 'ten, który wykonuje czynność wyrażoną czasownikiem, odnoszącą się do elementu rzeczywistości nazwanego rzeczownikiem lub w sposób wyrażony przymiotnikiem'. Pod względem struktury semantycznej wszystkie złożenia z tej grupy to złożenia nadrzędno-podrzędne egzocentryczne, gdzie człon czasownikowy jest nadrzędny, określany przez człon rzeczownikowy lub przymiotnikowy ${ }^{8}$. Pod względem formalnym formant interfiksalno-paradygmatyczny w czystej postaci występuje w 64 wyrazach, w 4 przypadkach w części odczasownikowej derywatu pojawia się ruchoma samogłoska, a w 14 - alternacja. Interfiks -e- występuje w 9 wyrazach, w pozostałych - interfiks -o-. W przeważającej większości derywaty uzyskały paradygmat rodzaju męskiego, z wyjątkiem wyrazu книгоноша, który jest rzeczownikiem wspólnorodzajowym (существительное общего рода) $)^{9}$.

$\mathrm{Na} 82$ rosyjskie złożenia z formantem paradygmatycznym przypada 96 polskich odpowiedników (zob. tabela 1). 22 wyrazy posiadają więcej niż jeden ekwiwalent, na przykład землекоn — kopacz, robotnik ziemny (odpowiednikami są derywat prosty i nazwa wielowyrazowa). W 9 przypadkach jeden polski ekwiwalent odpowiada kilku rosyjskim wyrazom będącym synonimami, na przykład: smolarz - смоловар, смологон, смолокур. Wśród polskich odpowiedników widać dużą różnorodność w realizacji sposobów nominacji. Znajdują się wśród nich wyrazy motywowane - derywaty proste i złożone, oraz wyrazy niemotywowane - wyrazy rodzime i zapożyczenia. Kolejną licznie reprezentowaną grupą, stojącą w opozycji do derywatów i wyrazów niemotywowanych, które traktuję łącznie jako nazwy syntetyczne (jednowyrazowe), są nazwy analityczne - dwu- i wielowyrazowe (nazwy złożone, zestawienia), to jest skonwen-

${ }^{7}$ M. Blicharski, Ztożenia imienne w języku rosyjskim i polskim. Studium konfrontatywne, Warszawa-Wrocław 1977, s. 57.

${ }^{8}$ Gramatyka wspótczesnego języka polskiego. Morfologia, t. 2, red. R. Grzegorczykowa, R. Laskowski, H. Wróbel, Warszawa 1999, s. 462-464.

9 Русская грамматика, t. 1, red. Н.Ю. Шведова, Москва 1980. 
cjonalizowane połączenia wyrazowe pełniące tę samą funkcję, co rzeczownik — nazywające określony element rzeczywistości ${ }^{10}$. Tłumaczenia opisowe wyrazów rosyjskich przytaczane są z kolei, gdy nie istnieje ekwiwalent znaczeniowy w języku polskim, co świadczy o tym, że język polski nie wykształcił nazwy dla danego zawodu bądź stanowiska.

Na 96 polskich ekwiwalentów 63 wyrazy są motywowane słowotwórczo (ponad dwie trzecie słownictwa w badanej grupie). Wśród nich występuje 49 derywatów prostych; $30 \mathrm{z}$ nich to derywaty odrzeczownikowe, na przykład: cukrownik, drwal, kamieniarz, 17 - odczasownikowe, na przykład: przewodnik, piekarz, nurek, 2 - odprzymiotnikowe: gorzelany, mierniczy. W przypadku derywatów odczasownikowych podstawą słowotwórczą jest czasownik wyrażający czynność, którą dana osoba wykonuje, dla derywatów rzeczownikowych — obiekt czynności wyrażony rzeczownikiem, derywaty odprzymiotnikowe są natomiast przykładami substantywizacji. Dla wszystkich tych derywatów w języku rosyjskim odpowiednikami są złożenia. Tam, gdzie w języku rosyjskim zaistniała potrzeba stworzenia nazwy zawodu czy stanowiska w oparciu o zarówno nazwę czynności, jak i jej obiektu, w języku polskim nazwy te utworzono, przyjmując za podstawę słowotwórczą jedno albo drugie.

Większość derywatów prostych to formacje sufiksalne, w przypadku $36 \mathrm{z}$ nich formantem jest sam sufiks, na przykład: browarnik, kamieniarz, rybak; występują również 4 przypadki sufiksacji w połączeniu z alternacją: mydlarz, piekarz, przewodnik, szklarz; a także 4 przykłady sufiksacji w połączeniu z ucięciem podstawy: alpinista, geometra, kucharz, nurek. 3 derywaty zostały utworzone poprzez zmianę paradygmatu: froter, astrolog, marynarz, przy czym w przypadku dwóch ostatnich w skład formantu wchodzi również ucięcie podstawy. Oprócz derywatów sufiksalnych występują także 2 wymienione wcześniej przykłady substantywizacji.

W badanej grupie znalazło się 14 złożeń. Pod względem budowy semantycznej są to złożenia nadrzędno-podrzędne egzocentryczne, nazywające wykonawców czynności. $10 \mathrm{z}$ nich ma strukturę $\mathrm{S}+\mathrm{V}$ : czarodziej, górołaz, rymopis, serowar, świniopas, brakorób, chleborób, piwowar, wierszokleta, miodosytnik; 3 złożenia mają odwrotną strukturę - V $+\mathrm{S}$ : nosiwoda, woziwoda, wyrwizą, co ciekawe, ich rosyjskie odpowiedniki to złożenia S + V: водонос, водовоз, зубодёp. Wynika to z faktu, że composita typu $\mathrm{V}+\mathrm{S}$ kilkukrotnie częściej występują w języku polskim niż $\mathrm{w}$ rosyjskim ${ }^{11}$. Jedno złożenie ma strukturę Adv $+\mathrm{V}$ : szybkobiegacz. We wszystkich przypadkach człon czasownikowy, niezależnie od tego, czy występuje w prepozycji czy postpozycji, jest członem nadrzędnym, określanym; człon drugi — rzeczownikowy lub przysłówkowy — jest członem określającym. Pod względem formalnym w złożeniach występuje interfiks -o-

10 J. Kaliszan, Семантико-конденсационная универбаиия составных наименований в современном русском языке, Poznań 1986, s. 7.

11 M. Blicharski, op. cit., s. 102-103. 
oraz -i-, w 1 przypadku (w wyrazie szybkobiegacz) - brak interfiksu ${ }^{12}$. Spośród 14 złożeń 12 zostało utworzonych za pomocą formantu paradygmatycznego, pozostałe 2 - za pomocą sufiksacji: szybkobiegacz, miodosytnik. Wszystkie composita są rzeczownikami rodzaju męskiego. $\mathrm{Z}$ analizy wynika, że na 82 złożenia $\mathrm{z}$ formantem paradygmatycznym $\mathrm{w}$ języku rosyjskim przypada tylko 12 polskich odpowiedników odzwierciedlających dokładnie tę samą strukturę i znaczenie.

Obok wyrazów motywowanych słowotwórczo w badanej grupie występuje 7 wyrazów niemotywowanych - są to wyrazy rodzime i zapożyczenia. Zarówno wyrazy motywowane, jak i niemotywowane mogą być traktowane jako nazwy syntetyczne (jednowyrazowe), które stoją w opozycji do nazw analitycznych (wielowyrazowych, złożonych) oraz do tłumaczeń opisowych. Tworzenie nazw wielowyrazowych można zaliczyć do niesłowotwórczych sposobów nominacji, natomiast w przypadku tłumaczenia opisowego nie można mówić wprost o działaniu mechanizmu nominacji; raczej o jego braku, ponieważ dana nazwa w języku ostatecznie nie powstała. Może to wynikać z faktu, że w konkretnym języku nie zaistniała potrzeba nazwania jakiegoś zjawiska lub w rzeczywistości pozajęzykowej to zjawisko nie występuje. Łącznie wśród polskich ekwiwalentów występują 33 przykłady niesłowotwórczych sposobów nominacji.

Wśród wyrazów niemotywowanych znajdują się 4 wyrazy rodzime: chtop, górnik, myśliwy, pątnik. Wyraz chłop jest pochodzenia ogólnosłowiańskiego (SEJP ${ }^{13}$, s. 62), pątnik w ujęciu diachronicznym jest wyrazem motywowanym, lecz synchronicznie jest uznawany za niemotywowany ze względu na zanik pierwotnej podstawy słowotwórczej — rzeczownika pąc (SEJP, s. 420). Wyrazy myśliwy i górnik są natomiast przykładami leksykalizacji — derywat i dawna podstawa słowotwórcza straciły więź semantyczną. Wyraz myśliwy powstał w wyniku substantywizacji przymiotnika, który pierwotnie miał znaczenie 'rozmyślający o czymś, uważny’, później nastąpił rozwój semantyki do dzisiejszego znaczenia łowcy ze względu na to, że łowiectwo uważano za zajęcie wymagające rozmyślności i skupienia (SEJP, s. 345). Pierwotny przymiotnik zaniknął, a co za tym idzie - zaniknęła również więź semantyczna z innymi wyrazami z tym samym rdzeniem. Kolejny przykład leksykalizacji — wyraz górnik — być może powstał pod wpływem języka niemieckiego i jest kalką wyrazu Bergmann (SEJP, s. 175). Do zapożyczeń na pewno należy natomiast wyraz pielgrzym, pochodzący z łaciny, zapożyczony za pośrednictwem języka włoskiego $\left(\mathrm{SWO}^{14}\right.$, s. 604), oraz flisak (SWO, s. 237) i szyper (SWO, s. 793) z języka niemieckiego.

Kolejną grupą są nazwy wielowyrazowe, przytaczane najczęściej wtedy, kiedy niemożliwe było znalezienie jednowyrazowego odpowiednika, na przykład: poławiacz krabów, hodowca bawetny, tkacz dywanów, obcinacz gałęzi. Łącznie

\footnotetext{
12 Gramatyka wspótczesnego języka polskiego..., s. 458.

13 W. Boryś, Stownik etymologiczny języka polskiego, Kraków 2005, dalej: SEJP.

${ }^{14}$ M. Jarosz, Stownik wyrazów obcych, Wrocław 2001, dalej: SWO.
} 
występuje ich $20.15 \mathrm{z}$ nich to połączenie rzeczownika odczasownikowego (subiekt czynności) z rzeczownikiem w dopełniaczu (obiekt czynności), w przypadku rosyjskich odpowiedników ta sama struktura semantyczna zawarta jest w złożeniach. W 3 przypadkach nazwa wielowyrazowa to grupa syntaktyczna typu atrybutywnego (rzeczownik w połączeniu z przymiotnikiem): człowiek pobożny, morski myśliwy, robotnik ziemny. W 2 przypadkach nazwy wielowyrazowe mają formę grupy syntaktycznej, składającej się z kilku wyrazów: pracownik zakładu przetwórstwa grzybów, robotnik w warzelni soli ${ }^{15}$. Tłumaczenia opisowe występują w 6 przypadkach, w sytuacji kiedy w języku polskim w ogóle nie istnieje dana nazwa zawodu lub stanowiska, na przykład: pracownik piekarni, zajmujacy się przygotowywaniem ciasta; specjalista zajmujacy się cięciem szkta; artysta rzeźbiacy w kości.

Powyższa analiza pokazuje, jak odmienne środki stosowane są w tworzeniu nazw zawodów i stanowisk w języku polskim, tam gdzie w analogicznej grupie $\mathrm{w}$ języku rosyjskim wystąpił jeden typ słowotwórczy — złożenie $\mathrm{z}$ formantem paradygmatycznym. Najliczniejsze są derywaty proste, stanowiące blisko połowę wszystkich analizowanych jednostek językowych. Kolejną liczną grupą są nazwy wielowyrazowe (około jedna piąta materiału), a dopiero trzecie miejsce zajmują złożenia (14 przykładów, co stanowi blisko jedną szóstą analizowanych nazw). Jest to konsekwencją faktu, że język polski przy tworzeniu pojęć złożonych częściej wybiera derywat prosty lub nazwę wielowyrazową ${ }^{16}$. Najmniej licznie reprezentowane są wyrazy niemotywowane oraz ekwiwalenty opisowe.

Zestawienie polskich odpowiedników wyrazów rosyjskich zostało przedstawione w tabeli 2. Sformułowanie bardziej szczegółowych wniosków będzie możliwe dopiero po zbadaniu całości materiału.

Tabela 1. Wyrazy rosyjskie oraz ich odpowiedniki w języku polskim

\begin{tabular}{|r|c|c|}
\hline Lp. & $\begin{array}{c}\text { Wyrazy } \\
\text { rosуjкkie }\end{array}$ & Polskie odpowiedniki \\
\hline 1. & банкомёm & bankier (w grach karcianych) \\
\hline 2. & богомаз & malarz ikon \\
\hline 3. & богомол & człowiek pobożny, pątnik, pielgrzym \\
\hline 4. & бракодел & brakorób \\
\hline 5. & верхолаз & robotnik pracujacy na dużych wysokościach \\
\hline 6. & винодел & producent (wytwórca) win, winiarz \\
\hline 7. & винокур & producent (wytwórca) spirytusu, gorzelany \\
\hline 8. & водовоз & woziwoda \\
\hline 9. & водолаз & nurek \\
\hline 10. & водолей & czerpacz \\
\hline 11. & водолив 1 & szyper \\
\hline
\end{tabular}

15 M. Blicharski, op. cit., s. 100-102.

16 Ibidem, s. 98. 


\begin{tabular}{|c|c|c|}
\hline Lp. & $\begin{array}{c}\text { Wyrazy } \\
\text { rosyjskie }\end{array}$ & Polskie odpowiedniki \\
\hline 12. & водолив 2 & czerpacz \\
\hline 13. & водонос & nosiwoda \\
\hline 14. & воскобой & pracownik woskowni \\
\hline 15. & грибовар & pracownik zakładu przetwórstwa grzybów \\
\hline 16. & дровокол & drwal \\
\hline 17. & дровосек & drwal \\
\hline 18. & живодёр & pracownik obdzierający zwierzęta ze skóry \\
\hline 19. & звездочёт & astrolog \\
\hline 20. & зверобой & morski myśliwy \\
\hline 21. & зверолов & towca, myśliwy \\
\hline 22. & землекоп & kopacz, robotnik ziemny \\
\hline 23. & землемер & mierniczy, geometra \\
\hline 24. & землероб & chleborób, chłop \\
\hline 25. & змеелов & łowca węży (żmij) \\
\hline 26. & зубодёр & wyrwizą \\
\hline 27. & каменотёс & kamieniarz \\
\hline 28. & кашевар & kucharz (w wojsku, $w$ artelu robotniczym) \\
\hline 29. & китобой & wielorybnik \\
\hline 30. & книгоноша & kolporter, roznosiciel książek \\
\hline 31. & ковродел & tkacz dywanów \\
\hline 32. & костоправ & kręgarz \\
\hline 33. & косторез & artysta rzeźbiacy w kości \\
\hline 34. & краболов & poławiacz krabów \\
\hline 35. & кукловод & marionetkarz, lalkarz \\
\hline 36. & лесоруб & drwal \\
\hline 37. & маслодел & maślarz \\
\hline 38. & медовар & miodosytnik \\
\hline 39. & мореход & żeglarz, marynarz \\
\hline 40. & мукомол & mtynarz \\
\hline 41. & мыловар & mydlarz \\
\hline 42. & пивовар & piwowar, browarnik \\
\hline 43. & плотовод & flisak \\
\hline 44. & плотогон & flisak \\
\hline 45. & полотёр & froter \\
\hline 46. & птицелов & ptasznik \\
\hline 47. & рифмоплёт & wierszokleta, rymopis \\
\hline 48. & рудокоп & górnik \\
\hline 49. & рыболов & rybak, wędkarz \\
\hline 50. & сахаровар & cukrownik \\
\hline 51. & свинопас & świniopas, świniarz \\
\hline 52. & скалолаз & wspinacz, alpinista, górołaz \\
\hline 53. & скирдоправ & stertnik, uktadacz stert (kop) \\
\hline 54. & скороход & $\begin{array}{c}\text { szybkobiegacz; zawodnik uprawiajacy jazde } \\
\text { szybka }\end{array}$ \\
\hline
\end{tabular}




\begin{tabular}{|c|c|c|}
\hline Lp. & $\begin{array}{l}\text { Wyrazy } \\
\text { rosyjskie }\end{array}$ & Polskie odpowiedniki \\
\hline 55. & следопыт & tropiciel \\
\hline 56. & смоловар & smolarz \\
\hline 57. & смологон & smolarz \\
\hline 58. & смолокур & smolarz \\
\hline 59. & солевар & robotnik $w$ warzelni soli \\
\hline 60. & сталевар & stalownik, wytapiacz stali \\
\hline 61. & стекловар & topiarz, hutnik (w hucie szkta) \\
\hline 62. & стеклодел & szklarz \\
\hline 63. & стеклодув & dmuchacz \\
\hline 64. & стеклорез & specjalista zajmujący się cięciem szkła \\
\hline 65. & стихоплёт & wierszokleta \\
\hline 66. & сучкоруб & obcinacz gatęzi \\
\hline 67. & сыровар & serowar \\
\hline 68. & сыродел & serowar \\
\hline 69. & тестомес & $\begin{array}{l}\text { pracownik piekarni, zajmujacy się przygo- } \\
\text { towywaniem ciasta }\end{array}$ \\
\hline 70. & тигролов & towca tygrysów \\
\hline 71. & трубочист & kominiarz \\
\hline 72. & углежог & wypalacz węgla, węglarz \\
\hline 73. & хлебопёк & piekarz \\
\hline 74. & хлеборез & krajacz chleba \\
\hline 75. & хлебороб & rolnik \\
\hline 76. & хлопкороб & hodowca bawetny \\
\hline 77. & чародей & czarodziej \\
\hline 78. & шаповал & folusznik \\
\hline 79. & шерстобит & 1. gręplarz; 2. folusznik, pilśniarz \\
\hline 80. & шерстобой & greplarz \\
\hline 81. & шерстовал & folarz, folusznik, pilśniarz \\
\hline 82. & экскурсовод & przewodnik \\
\hline
\end{tabular}

Tabela 2. Zestawienie polskich odpowiedników wyrazów rosyjskich

\begin{tabular}{|r|c|c|c|}
\hline Lp. & $\begin{array}{c}\text { Polskie odpowiedniki } \\
\text { wyrazów rosyjskich }\end{array}$ & $\begin{array}{c}\text { Typ odpowiednika ze względu } \\
\text { na sposób nominacji }\end{array}$ & $\begin{array}{c}\text { Odpowiadające wyrazy } \\
\text { rosyjskie }\end{array}$ \\
\hline 1. & alpinista & derywat prosty odrzeczownikowy & скалолаз \\
\hline 2. & $\begin{array}{c}\text { artysta rzeźbiący } \\
\text { w kości }\end{array}$ & thumaczenie opisowe & косторез \\
\hline 3. & astrolog & derywat prosty odrzeczownikowy & звездочёm \\
\hline 4. & $\begin{array}{c}\text { bankier }(w \text { grach } \\
\text { karcianych })\end{array}$ & derywat prosty odrzeczownikowy & банкомёm \\
\hline 5. & brakorób & złożenie S + V & бракодел \\
\hline 6. & browarnik & derywat prosty odrzeczownikowy & пивовар \\
\hline 7. & chleborób & złożenie S + V & землероб \\
\hline 8. & chłop & wyraz niemotywowany rodzimy & землероб \\
\hline
\end{tabular}




\begin{tabular}{|c|c|c|c|}
\hline Lp. & $\begin{array}{l}\text { Polskie odpowiedniki } \\
\text { wyrazów rosyjskich }\end{array}$ & $\begin{array}{l}\text { Typ odpowiednika ze względu } \\
\text { na sposób nominacji }\end{array}$ & $\begin{array}{l}\text { Odpowiadające wyrazy } \\
\text { rosyjskie }\end{array}$ \\
\hline 9. & cukrownik & derywat prosty odrzeczownikowy & сахаровар \\
\hline 10. & czarodziej & złożenie S + V & чародей \\
\hline 11. & czerpacz & derywat prosty odczasownikowy & водолей, водолив 2 \\
\hline 12. & człowiek pobożny & nazwa wielowyrazowa & богомол \\
\hline 13. & dmuchacz & derywat prosty odczasownikowy & стеклодув \\
\hline 14. & drwal & derywat prosty odrzeczownikowy & $\begin{array}{c}\text { дровокол, дровосек, } \\
\text { лесоруб }\end{array}$ \\
\hline 15. & flisak & $\begin{array}{l}\text { wyraz niemotywowany zapoży- } \\
\text { czony }\end{array}$ & плотовод, плотогон \\
\hline 16. & folarz & derywat prosty odczasownikowy & шерстовал \\
\hline 17. & folusznik & derywat prosty odczasownikowy & $\begin{array}{c}\text { шерстобит, шаповал, } \\
\text { шерстовал }\end{array}$ \\
\hline 18. & froter & derywat prosty odczasownikowy & полотёр \\
\hline 19. & geometra & derywat prosty odrzeczownikowy & землемер \\
\hline 20. & gorzelany & derywat prosty odprzymiotnikowy & винокур \\
\hline 21. & górnik & wyraz niemotywowany rodzimy & рудокоп \\
\hline 22. & górołaz & złożenie S + V & скалолаз \\
\hline 23. & greplarz & derywat prosty odczasownikowy & шерстобит, шерстобой \\
\hline 24. & hodowca bawetny & nazwa wielowyrazowa & хлопкороб \\
\hline 25. & hutnik (w hucie szkła) & derywat prosty odrzeczownikowy & стекловар \\
\hline 26. & kamieniarz & derywat prosty odrzeczownikowy & каменотёс \\
\hline 27. & kolporter & derywat prosty odczasownikowy & книгоноша \\
\hline 28. & kominiarz & derywat prosty odrzeczownikowy & трубочист \\
\hline 29. & kopacz & derywat prosty odczasownikowy & землекоп \\
\hline 30. & krajacz chleba & nazwa wielowyrazowa & хлеборез \\
\hline 31. & kręgarz & derywat prosty odrzeczownikowy & костоправ \\
\hline 32. & $\begin{array}{l}\text { kucharz ( } w \text { wojsku, } \\
\text { w artelu robotniczym) }\end{array}$ & derywat prosty odrzeczownikowy & кашевар \\
\hline 33. & lalkarz & derywat prosty odrzeczownikowy & кукловод \\
\hline 34. & lowca & derywat prosty odczasownikowy & зверолов \\
\hline 35. & towca tygrysów & nazwa wielowyrazowa & тигролов \\
\hline 36. & lowca węży (żmij) & nazwa wielowyrazowa & змеелов \\
\hline 37. & malarz ikon & nazwa wielowyrazowa & богомаз \\
\hline 38. & marionetkarz & derywat prosty odrzeczownikowy & кукловод \\
\hline 39. & marynarz & derywat prosty odrzeczownikowy & мореход \\
\hline 40. & maślarz & derywat prosty odrzeczownikowy & маслодел \\
\hline 41. & mierniczy & derywat prosty odprzymiotnikowy & землемер \\
\hline 42. & miodosytnik & złożenie $\mathrm{S}+\mathrm{V}$ & медовар \\
\hline 43. & mlynarz & derywat prosty odrzeczownikowy & мукомол \\
\hline 44. & morski myśliwy & nazwa wielowyrazowa & зверобой \\
\hline 45. & mydlarz & derywat prosty odrzeczownikowy & мыловар \\
\hline 46. & myśliwy & wyraz niemotywowany rodzimy & зверолов \\
\hline 47. & nosiwoda & złożenie V + S & водонос \\
\hline 48. & nurek & derywat prosty odczasownikowy & водолаз \\
\hline
\end{tabular}




\begin{tabular}{|c|c|c|c|}
\hline Lp. & $\begin{array}{l}\text { Polskie odpowiedniki } \\
\text { wyrazów rosyjskich }\end{array}$ & $\begin{array}{l}\text { Typ odpowiednika ze względu } \\
\text { na sposób nominacji }\end{array}$ & $\begin{array}{l}\text { Odpowiadające wyrazy } \\
\text { rosyjskie }\end{array}$ \\
\hline 49. & obcinacz gatęzi & nazwa wielowyrazowa & сучкоруб \\
\hline 50. & patnik & wyraz niemotywowany rodzimy & богомол \\
\hline 51. & piekarz & derywat prosty odczasownikowy & хлебопёк \\
\hline 52. & pielgrzym & $\begin{array}{l}\text { wyraz niemotywowany zapoży- } \\
\text { czony }\end{array}$ & богомол \\
\hline 53. & pilśniarz & derywat prosty odczasownikowy & шерстобит, шерстовал \\
\hline 54. & piwowar & złożenie $\mathrm{S}+\mathrm{V}$ & пивовар \\
\hline 55. & poławiacz krabów & nazwa wielowyrazowa & краболов \\
\hline 56. & $\begin{array}{l}\text { pracownik piekarni, } \\
\text { zajmujacy się przygo- } \\
\text { towywaniem ciasta }\end{array}$ & thumaczenie opisowe & тестомес \\
\hline 57. & pracownik woskowni & nazwa wielowyrazowa & воскобой \\
\hline 58. & $\begin{array}{l}\text { pracownik zaktadu } \\
\text { przetwórstwa grzybów }\end{array}$ & nazwa wielowyrazowa & грибовар \\
\hline 59. & $\begin{array}{l}\text { pracownik obdzie- } \\
\text { rajacy zwierzęta ze } \\
\text { skóry }\end{array}$ & thumaczenie opisowe & живодёр \\
\hline 60. & $\begin{array}{c}\text { producent (wytwórca) } \\
\text { spirytusu }\end{array}$ & nazwa wielowyrazowa & винокур \\
\hline 61. & $\begin{array}{l}\text { producent (wytwórca) } \\
\text { win }\end{array}$ & nazwa wielowyrazowa & винодел \\
\hline 62. & przewodnik & derywat prosty odczasownikowy & экскурсовод \\
\hline 63. & ptasznik & derywat prosty odrzeczownikowy & птицелов \\
\hline 64. & $\begin{array}{l}\text { robotnik pracujacy na } \\
\text { dużych wysokościach }\end{array}$ & thumaczenie opisowe & верхолаз \\
\hline 65. & $\begin{array}{l}\text { robotnik } w \text { warzelni } \\
\text { soli }\end{array}$ & nazwa wielowyrazowa & солевар \\
\hline 66. & robotnik ziemny & nazwa wielowyrazowa & землекоп \\
\hline 67. & rolnik & derywat prosty odrzeczownikowy & хлебороб \\
\hline 68. & roznosiciel książek & nazwa wielowyrazowa & книгоноша \\
\hline 69. & rybak & derywat prosty odrzeczownikowy & рыболов \\
\hline 70. & rymopis & złożenie S + V & рифмоплёт \\
\hline 71. & serowar & złożenie S + V & сыровар, сыродел \\
\hline 72. & smolarz & derywat prosty odrzeczownikowy & $\begin{array}{c}\text { смоловар, смологон, } \\
\text { смолокур }\end{array}$ \\
\hline 73. & $\begin{array}{l}\text { specjalista zajmujacy } \\
\text { się cięciem szkta }\end{array}$ & thumaczenie opisowe & стеклорез \\
\hline 74. & stalownik & derywat prosty odrzeczownikowy & сталевар \\
\hline 75. & stertnik & derywat prosty odrzeczownikowy & скирдоправ \\
\hline 76. & szklarz & derywat prosty odrzeczownikowy & стеклодел \\
\hline 77. & szybkobiegacz & złożenie Adv + V & скороход \\
\hline 78. & szyper & $\begin{array}{c}\text { wyraz niemotywowany zapożyc- } \\
\text { zony }\end{array}$ & водолив 1 \\
\hline 79. & świniarz & derywat prosty odrzeczownikowy & свинопас \\
\hline
\end{tabular}




\begin{tabular}{|c|c|c|c|}
\hline Lp. & $\begin{array}{l}\text { Polskie odpowiedniki } \\
\text { wyrazów rosyjskich }\end{array}$ & $\begin{array}{l}\text { Typ odpowiednika ze względu } \\
\text { na sposób nominacji }\end{array}$ & $\begin{array}{c}\text { Odpowiadające wyrazy } \\
\text { rosyjskie }\end{array}$ \\
\hline 80. & świniopas & złożenie S + V & свинопас \\
\hline 81. & tkacz dywanów & nazwa wielowyrazowa & ковродел \\
\hline 82. & $\begin{array}{l}\text { topiarz (w hucie } \\
\text { szkła) }\end{array}$ & derywat prosty odczasownikowy & стекловар \\
\hline 83. & tropiciel & derywat prosty odczasownikowy & следопыт \\
\hline 84. & uktadacz stert (kop) & nazwa wielowyrazowa & скирдоправ \\
\hline 85. & wędkarz & derywat prosty odrzeczownikowy & рыболов \\
\hline 86. & węglarz & derywat prosty odrzeczownikowy & углежог \\
\hline 87. & wielorybnik & derywat prosty odrzeczownikowy & китобой \\
\hline 88. & wierszokleta & złożenie S + V & стихоплёт, рифмоплёт \\
\hline 89. & winiarz & derywat prosty odrzeczownikowy & винодел \\
\hline 90. & woziwoda & złożenie $\mathrm{V}+\mathrm{S}$ & водовоз \\
\hline 91. & wspinacz & derywat prosty odczasownikowy & скалолаз \\
\hline 92. & wypalacz wegla & nazwa wielowyrazowa & углежог \\
\hline 93. & wyrwizab & złożenie V + S & зубодёр \\
\hline 94. & wytapiacz stali & nazwa wielowyrazowa & сталевар \\
\hline 95. & $\begin{array}{l}\text { zawodnik uprawiaja- } \\
\text { cy jazdę szybka }\end{array}$ & tłumaczenie opisowe & скороход \\
\hline 96. & żeglarz & derywat prosty odczasownikowy & мореход \\
\hline
\end{tabular}

\section{Bibliografia}

\section{Źródła}

Boryś W., Stownik etymologiczny języka polskiego (SEJP), Wydawnictwo Literackie, Kraków 2005. Jadacka H., Bondkowska M., Słownik gniazd słowotwórczych wspótczesnego języka ogólnopolskiego, t. 2. Gniazda odrzeczownikowe (SGSWJO 2), Historia Iagellonica, Kraków 2001.

Jarosz M., Stownik wyrazów obcych (SWO), Europa, Wrocław 2001.

Vogelgesang T., Słownik gniazd słowotwórczych współczesnego języka ogólnopolskiego, t. 1. Gniazda odprzymiotnikowe (SGSWJO 1), Historia Iagellonica, Kraków 2001.

Skarżyński M., Stownik gniazd słowotwórczych współczesnego języka ogólnopolskiego, t. 4. Gniazda motywowane przez liczebniki, przystówki, zaimki, przyimki, modulanty, onomatopeje, wykrzykniki (SGSWJO 4), Historia Iagellonica, Kraków 2004.

Skarżyński M. et al., Stownik gniazd słowotwórczych wspótczesnego języka ogólnopolskiego, t. 3. Gniazda odczasownikowe, cz. 1-2 (SGSWJO 3), Historia Iagellonica, Kraków 2004.

Русский семантический словарь. Толковый словарь, систематизированный по классам слов и значений (РСС), t. 1, ред. Н.Ю. Шведова, Азбуковник, Москва 2002.

Тихонов А.Н., Словообразовательный словарь русского языка (ССРЯ), t. 1-2, Астрель, Москва 2003. 


\section{Literatura}

Blicharski M., Złożenia imienne w języku rosyjskim i polskim. Studium konfrontatywne, PWN, Warszawa-Wrocław 1977.

Dokulil M., Ke koncepci porovnávaci charakteristiky slovanských jazyků v oblasti „tvořeni slov”, „Slovo a slovesnost” 24, 1963, z. 2.

Gramatyka współczesnego języka polskiego. Morfologia, t. 1-2, red. R. Grzegorczykowa, R. Laskowski, H. Wróbel, PWN, Warszawa 1999.

Kaliszan J., Семантико-конденсационная универбаиия составных наименований в современном русском языке, Wydawnictwo Naukowe Uniwersytetu im. Adama Mickiewicza w Poznaniu, Poznań 1986.

Ogólnostowiański atlas językowy. Seria leksykalno-stowotwórcza, t. 8. Zawody i życie społeczne, red. J. Basara, J. Siatkowski, A. Basara, Instytut Języka Polskiego PAN, Warszawa 2003.

Rusek J., Dzieje nazw zawodów w językach stowiańskich, Wydawnictwo Energeia, Warszawa 1996.

Siatkowski J., Słowiańskie nazwy wykonawców zawodów w historii i dialektach, Uniwersytet Warszawski. Wydział Polonistyki. Instytut Slawistyki Południowej i Zachodniej, Warszawa 2005.

Исаченко А.В., К вопросу о структурной типологии словарного состава славянских литературных языков, „Slavia” 27, 1958, z. 3.

Русская грамматика, t. 1, red. Н.Ю. Шведова, Наука, Москва 1980.

Улуханов И.С., Мотивация в словообразовательной системе русского языка, Азбуковник, Москва 2005.

\section{Compound Nouns Formed with Paradigmatic Formant in the Lexical-Semantic Group "The Names of People Related to Their Profession" in Russian Language and Their Polish Equivalents}

\section{Summary}

The scientific goal of this article is to examine the vocabulary in analogic lexical-semantic groups taken from two Slavic languages - Russian and Polish — in terms of word-formative and non-word-formative ways of nominations. The subject of research is the names of people, related to their profession, occupation, specialty, type of occupation, the nature of business. The basis for the selection of the material is The Russian Semantic Dictionary (ed. N.Y. Shvedova). From over 2750 names in Russian, one type of derivates - compound nouns formed with paradigmatic formant — has been chosen for further analysis ( 82 words). The Polish equivalents ( 96 words and expressions) have been divided into two groups: motivated words (63 words) and broadly defined unmotivated words and expressions, which represent non-word-formative ways of nominations (33 examples), such as native words (4), loanwords (3), compound names (20) and descriptive translations, when lexical equivalents could not be found (6). One type of derivate in the Russian lexical group and the variety of equivalents in Polish show the differences in terms of ways of nominations in parallel lexical groups in both languages.

Keywords: nomination, word formation, compound noun, derivate, unmotivated word 


\section{Сложения с нулевым суффиксом}

в лексико-семантической группе «Назвния лиц по профессии» в русском языке и их польские эквиваленты

\section{Резюме}

Целью данной статьи является анализ типов польских эквивалентов для сложений с нулевым суффиксом, выступающих в лексико-семантической группе «Названия лиц по профессии, специальности, роду занятий, характеру деятельности» в русском языке. Базой для отбора материала послужил Русский семантический словарь под ред. Н.Ю. Шведовой. Среди около 2750 слов в этой группе, 82 - сложения с нулевым суффиксом. Их польские семантическе эквиваленты (96 слов и выражений) можно разделить на две группы: мотивированные слова (63) как результат словообразовательного способа номинации и слова и выражения, которые представляют собой несловообразовательные способы номинации (33): исконные слова (4), заимствования (3), составные наименования (20) и описательные переводы (6), приводимые в случае, когда в польском языке нет лексического соответствия. Такая разновидность эквивалентов в польском языке для одного типа дериватов в русском языке свидетельствует о том, что в обоих языках по-разному реализованы механизмы номинаци в рамках параллельных лексико-семантических групп.

Ключевые слова: номинация, словообразование, сложение, дериват, немотивированное слово 